\title{
The Political Unconscious in Jane Eyre, Wuthering Heights, and Great
}

\section{Expectations}

\author{
Jane Eyre, Ŭgultulu Tepeler ve Büyük Umutlar'da Siyasal Bilinçdışı \\ Hale KÜÇÜK*
}

\begin{abstract}
This paper aims to explore three Victorian novels, namely Charlotte Brontë's Jane Eyre (1847), Emily Brontë's Wuthering Heights (1847), and Charles Dickens's Great Expectations (1861) bringing together Marxist and postcolonial theories. While some novels written in the Victorian era deal with imperialism and the colonized overtly, in these three novels, the colonies and the colonized are dealt with indirectly as if only in passing. However, these in-passing references are very significant because they constitute the recurrent silences, gaps, and absences in these texts, which has critical implications. In Marxist terms, it is history that haunts these texts in these gaps and silences, which means that these Victorian novels are inevitably related to Britain's imperial history and its ideologies. What is given repeatedly at the margins or gaps of these texts demonstrates the obsessive return of the issue of colonialism though the texts seek to repress it. Exploring the return of the colonial repressed in the gaps and silences of these novels by focusing on Fredric Jameson's conception of the political unconscious, this paper argues that these novels have twofold function: while expressing the deep-seated anxieties, fears, and desires of Victorian society by projecting them onto the non-white others, they contribute to shape a certain understanding of the colonized other and also a certain sense of national identity.
\end{abstract}

Keywords: The Political Unconscious, Colonialism, Imperialism, Jane Eyre, Wuthering Heights, Great Expectations.

$\ddot{O} z$

Bu çalışma Marksist ve kolonyal dönem sonrası teorileri birleştirerek üç Viktoryen romanı, Charlotte Brontë’nin Jane Eyre (1847), Emily Brontë'nin Uğultulu Tepeler (1847) ve Charles Dickens'ın Büyük Umutlar'ını (1861) incelemeyi amaçlamaktadır. Viktoryen dönemde yazılmış bazı romanlar emperyalizm ve sömürüleni açık bir şekilde ele alsa da bu üç romanda sömürgeler ve sömürülen direk olarak ele alınmaz ve sanki geçiştirilir. Ancak bu geçiştirmeler çok önemlidir çünkü bunlar, bu metinlerde kritik bir anlam taşıyan ve sürekli olarak tekrarlayan suskunlukları, boşlukları ve eksikleri teşkil etmektedirler. Marksist bağlamda, bu metinlerin boşluk ve suskunluklarında beliren şey tarihtir, yani bu Viktoryen romanlar ister istemez Britanya'nın emperyalist tarihiyle ve onun ideolojileriyle ilintilidir. Bu metinlerin marjinlerinde veya boşluklarında sürekli olarak ele alınan konular, metinler bunu bastırmaya çalışsa da kolonyal bastırılanın geri dönüşünü göstermektedir. Fredric Jameson'un siyasal bilinçdışı kavramına odaklanarak bu metinlerdeki boşluk ve suskunluklarda ortaya çıkan kolonyal bastırılanı inceleyen bu çalışma, bahsedilen romanların ikili bir işlevi olduğunu öne sürmektedir: bir yandan Viktoryen toplumun yerleşmiş kaygı, korku ve arzularını beyaz olmayan öteki üstünden anlatırken bu eserler belirli bir sömürülen öteki ve aynı zamanda belirli bir millî kimlik algısı oluşturmaktadırlar.

Anahtar Kelimeler: Siyasal Bilinçdışı, Sömürgecilik, Emperyalizm, Jane Eyre, Uğultulu Tepeler, Büyük Umutlar.

\section{Introduction}

"[I]mperialism and the novel fortified each other to such a degree that it is impossible. . . to read one without in some way dealing with the other" (Said, 1994, p. 71). Although imperialism as an ideology seems to be the strongest towards the later decades of the nineteenth century, the "early and mid-Victorian Britons were not 'absent-minded' about the Empire" (Brantlinger, 2009, pp. 4, 6). While some novels in the Victorian era deal with imperialism and the colonized overtly, in some others such as Charlotte Brontë's Jane Eyre (1847), Emily Brontë's Wuthering Heights (1847), and Charles Dickens's Great Expectations (1861), the colonies, the colonized and the colonial exploitation are "referred to only in passing" as Edward Said (1994) also points out in his Culture and Imperialism specifically with regard to the nineteenth century novels such as Mansfield Park, Jane Eyre, David Copperfield, and Great Expectations among many others (p. 89). However, these in-passing references are very significant

\footnotetext{
* MEB Öğretmeni, Orta Doğu Teknik Üniversitesi, Eğitim Fakültesi, İngiliz Edebiyatı Programı Doktora Öğrencisi, hkucuk@yahoo.com.
}

Küçük, H. (2019). The Political Unconscious in Jane Eyre, Wuthering Heights, and Great Expectations, Gaziantep University Journal of Social Sciences, 18 (4), 1242-1254, Submission Date: 27-03-2019, Acceptance Date: 1810-2019.

Araştırma Makalesi. 
because they constitute certain silences, gaps, and absences in these texts. In his A Theory of Literary Production, Pierre Macherey (1966) invites us to read texts with an eye for the gaps, silences, and margins since they form a "certain absence" (p. 94, emphasis original). Drawing upon Freud's theory of the unconscious, Macherey underlines the critical importance of what a text "does not say" (1966, p. 97). For him, what happens at the margins of a text is "produced under determinate conditions" (p. 88, emphasis original). That is, the context or history determines what a text can articulate. Similarly, drawing on Freud, to a certain extent, Fredric Jameson (1983) sees the narrative as a socially symbolic act as indicated in the title of his The Political Unconscious: Narrative as a Socially Symbolic Act. He remarks, "there is nothing that is not social and historical- indeed, ... everything is 'in the last analysis' political"; and he proposes a political unconscious inherent in each and every cultural product (1983, p. 5). In fact, his conception of the political unconscious can be traced through the absences and silences of the Victorian novels studied here. What is repeatedly given at the margins of some texts can be regarded as "the uncanny" as they indicate "the constant recurrence of the same thing" (Freud, 1899, p. 142). The "unintentional return" of the repressed which leads to a "compulsion to repeat" and which creates the sense of the uncanny is related to what Macherey sees as the unacknowledged silences or absences (Freud, 1899, pp. 144, 145). These instances in the narrative reveal the limits set for the text by history for both Macherey and Jameson. This is the point that these Marxist figures come close to Said who argues that writers are shaping and shaped by the history of the society they live in and by their social experiences in that society (1994, p. xxii). Then, it can be assumed that the nineteenth century realist novels, especially those that do not seem to deal with imperialism and colonialism directly and just refer to them only in passing, are the ones which perhaps unintentionally express the return of the colonial repressed. In this regard, this study claims that these novels have a twofold function: while expressing the deep-seated anxieties, fears, and desires of Victorian society by projecting them onto the non-white others, they contribute to shape a certain understanding of the colonized other and also a certain sense of national identity. This argument can be explored by looking at the workings of the political unconscious in these texts.

In fact, some strong Marxist, Freudian, and postcolonial readings of the aforementioned novels have already been made. This study will offer a slightly different approach by bringing together Marxist and postcolonial theories. The focus of this paper is not how the colonized subject or space is represented in these Victorian novels, but rather how it is represented at the margins, gaps, and absences of the texts, and the critical implications of these references. By looking at the margins and silences in these novels, one can have a better understanding of the functions of the Jamesonian concept of the political unconscious of these texts. Moreover, this line of thinking juxtaposed with a postcolonial viewpoint sheds light on the relationship among literature, society, culture, and history.

According to Jameson, literary works are informed by a political unconscious as "all literature must be read as a symbolic meditation on the destiny of community" (1983, p. 56). He builds up his theory on the idea of the contradiction between social classes. Following Marx and Engels, he points out:

The history of all hitherto existing society is the history of class struggles: freeman and slave, patrician and plebian, lord and serf ... -in a word, oppressor and oppressed- stood in constant opposition to one another, carried on an uninterrupted, now hidden, now open fight (p. 4).

He adds that "It is in detecting the traces of that uninterrupted narrative, in restoring to the surface of the text the repressed and buried reality of this fundamental history, that the doctrine 
of political unconscious finds its function and necessity" (p. 4). Thus, to him, the political unconscious is a convenient tool to unmask "cultural artifacts as socially symbolic acts" (p. 5). Three concentric horizons form his interpretive framework. These are the political, social, and historical horizons. The historical horizon includes the social which includes the political. In the political horizon, his focus is on the individual text which is regarded as a "symbolic act" (p. 61, emphasis original). The literary text is a symbolic act as it proposes utopian resolutions to the actual social contradictions in the society. In the social horizon, he focuses on the struggle between the social classes. The text at this point is almost an "individual parole or utterance" of "the great collective and class discourses" (p. 61, emphasis original). In the historical horizon, he conceives history through the modes of production. He regards the individual text and its "ideologemes" as "the smallest intelligible unit of the ... antagonistic collective discourses of social classes" and interprets this as the "ideology of form" (pp. 61, 62, emphases original).

This study explores the aforementioned Victorian novels as they are situated in the first horizon, that is, the political. In the political horizon, "history is reduced to a series of punctual events and crises in time"; and the individual text is regarded as "the imaginary resolution of a great contradiction" (Jameson, 1983, p. 62). A literary work or cultural artifact is ideological. The resolution of social contradictions that takes place in a narrative can only be of illusory nature because these contradictions are "unresolvable" in real life (Jameson, 1983, p. 64). From a postcolonial perspective, what Jameson sees as social classes can be considered as different racial communities. As Patrick Brantlinger notes, "Racism functions as a displaced or surrogate class system"; and "in the Empire the conquered races were treated as a new proletariat, their status much less distinct from slavery than that of the working class at home" (1988, p. 184). Then, the colonized and the colonizer or different racial groups can arguably be grasped as in class contradictions in the novels which employ characters of non-British origins and which refer to colonialism. In the novels studied in this paper, the colonized character either acts from within the periphery and disturbs the order at the centre; or if $s /$ he is a central figure, the text first employs her/him in order to work out some problems in the society in that period, and then displaces that character in an attempt to provide the Jamesonian imaginary resolutions to the problems at home or in England. Jameson (1983) believes that in the struggle of the antagonistic classes, the ruling class strives to legitimate its own position while the oppositional class or culture contests in hidden and disguised strategies to "undermine the dominant "value system"" (p. 69). However, it can be argued that the silences or absences of these novels do not seem to allow much space to the struggle of the colonized. They rather try to repress it. These novels seek to master the colonial presences and voices in line with their own agendas. Said, Macherey, and Jameson all draw attention to the context which enables a writer to produce works the way $\mathrm{s} /$ he does. It is Britain's imperial history which enables these novels to refer to colonialism and imperialism with a blind eye to the colonized and their plight. The novels do not contest the ideology of imperialism. On the contrary, they are informed by it. They, in turn, contribute to it by viewing the "British dominance ... [ [as] a sort of norm" as claimed by Said (1994, p. 74).

Underlining the contribution of the nineteenth century novels to the British imperial policy, Said (1994) notes that the main purpose of these works is not to question this policy or to draw attention to it, "but to keep the empire more or less in place" (p. 74). He contends that the Empire became "a principal subject of attention" only after the mid-nineteenth century "in writers like Haggard, Kipling, Doyle, Conrad" and adds that until mid-century, the Victorian novelists who mentioned or referred to the periphery maintained the idea that "outlying territories are available for use, at will, ... usually for relatively simple purposes such as immigration, fortune, or exile" (p. 74). This is exactly how the thereabouts or the colonized subjects are represented in the novels studied in this paper. Although these novels are set mostly in England, they refer to the other races and imperialism in such ways that while inevitably reflecting how 
the colonial exploitation and imperialism influence the lives of the characters at the centre, these novels do not draw reader's attention to what is going on in the colonies. Put differently, the focus is always on England, not the colonized countries or subjects. In Jane Eyre, for instance, reader's attention is directed mostly to the portrayal of Jane, the protagonist, and the struggles of this rebellious female character to build up a space for herself as an independent woman in the patriarchal society. In Wuthering Heights, the focus is on the mystical love affair between Heathcliff and Catherine, and the evil nature of dark-skinned Heathcliff. The resolution is enacted through the love affair and imminent consummation of the second generation, but only after the member of the threatening class, namely Heathcliff, is exterminated as it is with Creole Bertha in Jane Eyre. Great Expectations is generally interpreted as the bildung of the protagonist, Pip. It is a rags-to-riches story which ends in Pip's becoming a mature man who may get married to his love, Estella. Magwitch, the convict transported to Australia, makes Pip a gentleman to a certain extent while he lives in the penal colony. However, his experience there remains as an absence in the text. The seemingly simple purposes as Said calls them, such as Jane's inheritance derived from the colonial space or the transportation of the convicts to the colonies, are by no means simple because through these simple references one can trace the political unconscious of these texts, which shows that these texts are in keeping with the imperialist cause. The colonial references are employed as a means to deal with the problems in England such as woman's position, class hierarchy and mobility in the society, rising crime rates, the surplus population, and the influx of slaves. Yet, these references have another function, too. By referring to the colonial space or the colonized races without bringing these matters to the fore, these novels reflect the anxieties, problems, and desires of English society and simultaneously shape a certain understanding of Britishness and otherness. That is why in these novels, "it is the silence that is doing the speaking" (Macherey, 1966, p. 96).

In Jane Eyre, although she shapes the events taking place in the main characters' lives to a certain extent, Bertha is an absent presence. She is allowed no voice. She only laughs in an odd and tragic way, bellows, moans, groans, or talks gibberish. The reader is never given her true history from her own voice. The novel traps this mysterious madwoman in the conventions of the Gothic to follow its own feminist agenda. Her "demonic laugh" is "low, suppressed and deep" (Jane Eyre, p. 126). She emerges at nights at the door of Jane's room. Her presence and criminal acts, which haunt Jane and make her shudder each time, are tried to be kept as a secret by Rochester and the servants. Moreover, she is portrayed like an animal and a true lunatic because throughout the novel she is referred to as the mad woman, "devil", "a savage", "a goblin", the "maniac", and a wild beast (Jane Eyre, pp. 126, 175, 178, 250). She is not given an identity of her own in the novel which is, ironically, regarded as a proto-feminist text. It is important to note that the text refers to her threatening presence while revealing Jane's sexual awakening. Sandra M. Gilbert and Susan Gubar (1979) think that her presence is a part of Jane's own story and assert that Bertha is Jane's "truest, darkest double: she is the angry aspect of the orphan child, the ferocious secret self Jane has been trying to repress" (p. 360). They underline Bertha's function in the novel as: "every one of Bertha's appearances . . . has been associated with an experience (or repression) of anger on Jane's part" (p. 360). Jane's feelings of "hunger, rebellion, and rage" are reflected through the madwoman's laughs and murmurs; Jane's anxieties about marriage, sexuality, and hostility towards Rochester are enacted by Bertha's actions such as tearing of the bridal veil and the bodily mutilation of Rochester (Gilbert \& Gubar, 1979, p. 361). In other words, for Gilbert and Gubar, Bertha acts out "Jane's secret fantasies" (p. 361). These are sexual fantasies because while Rochester calls her "[my] girl-bride" indicating her virginity, he claims that Bertha has been a "partner" with some "excesses", which points to her excessive sexuality (Jane Eyre, pp. 220, 261). Gilbert and Gubar's arguments are contested by 
Gayatri C. Spivak (1985) who observes that the writer makes "human/animal frontier as acceptably indeterminate" through Bertha and thinks that this is "the register . . . of Europe and its not-yet-human Other, of soul making" (p. 247). In fact, both views serve the argument of this paper. The arguments of Gilbert and Gubar reflect how the psychological state of the English woman is projected onto the Creole woman and tried to be solved through her. Both their and Spivak's claims demonstrate that the savagery and the evil nature of the colonized are made use of to build up the subjectivity of Jane, to enable her to resolve the sexual and social problems she experiences on her way to sexual fulfillment and independence as a woman.

In Susan Meyer's reading, the novel uses the non-white races in its representation of both the oppressors and the oppressed. The logic it follows is that "oppression in any of its manifestations is foreign to the English" (Meyer, 1996, p. 81). Although she is never let to speak her mind, Bertha, as the symbolic other, is represented as a threat to the domestic space. She attacks Rochester and her own brother and, in an indirect way, hinders Jane's marriage to Rochester. In the end, she sets Thornfield on fire destructing herself and maiming Rochester. For Rochester, Jane, and the text, these reflect her savage nature, criminal bent, madness, and, in one sense, her agency which is capable of only injury and destruction. In its references and allusions to Bertha and the other non-white people such as the oriental inmates of the seraglio whom Jane compares herself to (Jane Eyre, p. 229-230), the concern of the novel is the British who are somehow "contaminated by their contact with the unjust social systems indigenous to the people with dark skin" (Meyer, 1996, p. 81). In so doing, the novel attempts to hide or suppress the British imperialist domination according to Meyer. The other strategy employed by the novel to work out the actual problems in Victorian England is cleaning the domestic space "to create a domestic, English world free of oppression" (Meyer, 1996, p. 91). The novel cleans out the domestic space by means of the death of Bertha. When the contaminating effect of the imperial history and the traces of the colonized other are cleaned away, the novel can end with marriage which is an institution to reproduce the norms and values of the society. Yet, considering Jameson's ideas, this is just a utopian closure which cannot erase the problems and anxieties in Victorian England. For instance, Rochester's moral failure in his attempt to find the ideal woman ends in an illegitimate child, Adèle. This is not acceptable in Victorian society. However, he puts the blame on Bertha. For him, it is Bertha and his marriage to her which cause his life turn into hell. She is the "curse" with which he is burdened (Jane Eyre, p. 265). He uses the Creole woman to cover up his transgression of Victorian moral code.

Moreover, the novel invites the reader to make a comparison between Jane and Bertha. In this comparison, while independence, rationality, and civilisation are associated with the English woman, dependency, madness, and savagery are associated with the Creole party. Yet, this comparison cannot eradicate the oppression of woman in the patriarchal society of that time which sees sexual desire of woman as an excess. The novel also reflects phobias of Victorian women as regards the marriage institution such as being bought and sold like an object and treated like an animal. Elsie Michie (1992) argues that Rochester is an embodiment of the "figure of the oriental despot" and adds that fantasies of women such as "resisting . . . domination and appropriation" are also worked out from over the racial other when, for instance, Jane identifies herself with the inmates of harem and articulates her rebellious nature and desire for freedom (pp. 135, 137). While foregrounding the independence of the British woman, the novel evades raising any questions as to Bertha's captivity and her history.

Tracing the source of money in Jane Eyre can be one of the paths that can lead to the "unmasking" of the novel as a "socially symbolic act" in Jamesonian terms (1983, p. 5). The source of income of Rochester is one point that the text overlooks. It is just referred to. The reader is not informed about this issue. Rochester is a wealthy gentleman thanks to his father 
and brother who arrange his marriage to Bertha for material gain. It is the dowry the Creole woman brings to him which makes him what he is. What is a problem for Jane is transformed and projected onto the woman from Jamaica at this point. The novel is concerned with the anxiety about the "positioning of women as property", yet it "projected or extrojected [this anxiety] onto the "Orient'" (Michie, 1992, p. 135). An analogy can be made between marriage and colonialism since both have an economic aspect. In marriage, woman, as an object of exchange, makes a man richer; in colonialism, the colonizer becomes prosperous by means of colonial exploitation. However, imperial history causes the latter to be ignored by the novel. While Jane contests the conventional idea of woman as man's property, she keeps silent about the colonized people as a source of income for the British.

Likewise, Jane's uncle is repeatedly mentioned as being abroad. However, what he does there, by what means he amasses a great sum of money are gaps in the novel. He is in Maderia. He sends some letters and notes from there, but these are hidden from Jane by Mrs. Reed, her aunt. For instance, his letter that announces his wish to have young Jane with him in Maderia is unknown to Jane. Rather than what goes on in Africa or how this sum is made, the novel deals with what Jane does with this sum of money when she inherits it. She is positioned on an equal footing with Rochester by means of this inheritance. She can marry him as an economically independent woman. She thinks that now that she is rich "independence would be glorious" (Jane Eyre, p. 326). However, as Meyer (1996) remarks:

The location of Jane's uncle John in Maderia, off Morocco, on the West African coast, where Richard Mason stops on his way home from England, ... indirectly suggests, through Mason's itinerary, the triangular route of the British slave traders, and suggests that John Eyre's wealth is implicated in the slave trade (p. 93).

Then, the plight of the colonized thereabouts is for the well-being of those at the centre. The text focuses only on independence of the heroine and keeps silent about slavery of the darkskinned races. Imperialism had another motive beside civilising the so-called savage race. That is, Britain economically depended on its colonies. The text tries to repress this historical fact. As Jameson puts, our approach to history "necessarily passes through its narrativization in the political unconscious" of the cultural works or literary texts (1983, p. 20). The silences of the text about imperial expansion and slave trade demonstrate that it is produced under certain conditions and that it reinforces these conditions.

Conversion of the heathen race to Christianity was one leg of the imperialist project, which rendered it legitimate in the eyes of Victorian society. St. John, Jane's cousin and a clergyman, wants to marry her and take her to India where he will go for missionary work. Although St. John's marriage proposal is treated by the text in relation to what Jane should do next, that is, her personal choices and her own pilgrimage, it seems that St. John, Jane, and the novel approve of the missionary work. Jane reiterates that he will do a "great task" there which entails personal sacrifice and which is a "noble" attempt that would breed "sublime results" (Jane Eyre, p. 343, 344). She could accept accompanying him as long as she goes there as a comrade, not as his wife. Due to his despotic attitude towards her, she refuses his proposal. Nevertheless, St. John, despite his despotism, is "both the martyr and the hero" of the novel (Eagleton, 1975, p. 20). It is important that the novel ends celebrating St. John who is called a "warrior Greatheart" (Jane Eyre, p. 385). Michie's abovementioned claim about the figure of the oriental despot can be traced in the characterization of St. John as well. Jane finds his despotism unbearable. At this point a shift emerges in his portrayal: the despot at the centre becomes a saintly figure when he is in the colony. The novel turns the problem of male despotism into a celebration of the missionary work. Jane's anxiety about gender inequality and her fear of marriage without pas- 
sion are resolved when he goes to the colonies. Meanwhile, instead of questioning the legitimacy of the missionary work, the novel resolves the contradiction between the colonizer and the colonized races as regards the issue of religion siding with the heroes of the British nation. The novel grasps the conversion issue as a war against the other races and other religious systems. The usage of war metaphor reminds one of the military aspect of colonialism and the bloodshed that took place in the colonies. However, these are evaded by the novel. If the British missioner is acknowledged as a hero in this war, then, the colonized subjects are the heathens who need to be educated according to the novel.

Like Jane Eyre, Wuthering Heights employs a racially differentiated character, Heathcliff, in order to work out the social problems of Victorian society from over this dark-skinned character and to build up a certain understanding of the racial other, which, in turn, could help to construct a certain conception of British identity. Unlike Bertha, Heathcliff seems to be more monstrous. He is at the centre of the novel and is given voice. However, still, the novel has gaps and ambiguities about Heathcliff. He is brought home by old Earnshaw upon a visit to Liverpool. As the novel does not inform the reader as to his origins, both the critics and the other characters in the novel can only speculate about him and his origins. He becomes almost a symbol of the other races. For Eagleton (1975), Heathcliff can be of Irish origin as Liverpool was the centre of the slave trade in that time (p. xix). For Howard Malchous (as cited in Brantlinger, 2009), he is "the mixed-race offspring of a British sailor and an enslaved African woman" (p. 72). For the other characters in the novel, it seems that there is no need to trace the origin of this dark-skinned "gipsy brat", as his appearance, which is non-English, is enough for them to criticise, punish, ostracise him and fix him in a certain category throughout the novel (Wuthering Heights, p. 29). His presence poses a threat to almost all characters around him. He comes from an unknown place and becomes a master. Contamination and corruption are what he introduces to the decent English houses. The Lintons, the representatives of gentry, wonder why old Earnshaw has this stranger at home because he is "quite unfit for a decent house" (Wuthering Heights, p. 40). If this novel aims to demystify Victorian ideal of the domestic space and to show that it is not that peaceful, one question to be raised is why the writer chooses a dark-skinned character to disturb this space? In "mid-century England ... the problems of race and slavery did not vanish with emancipation" despite Britain's abolition of the slave trade in 1807 and the emancipation of the slaves in the colonies in 1834 (Von Sneidern, 1995, p. 175). It seems that anxieties about slavery and the fear of being invaded by the colonized races haunt Victorian society.

Like Bertha who is represented in Gothic conventions, the portrayal of Heathcliff has Gothic aspects. Wuthering Heights is a Gothic setting with its locked rooms, brutal dogs, ghosts, violence, and hatred of the characters' to one another. These are in parallel with the representation of the savagery of Heathcliff. He is the embodiment of backwardness, savagery, and violence, which is what the Empire seemed to fight against in the Victorian age. What Nelly, one of the narrators, and the other characters say of him continually adds up to the image of his savagery. Nelly reflects on the day Heathcliff was introduced to the family and mentions how Catherine, daughter of Earnshaw, spat at the "stupid little thing" (Wuthering Heights, p. 30). Nelly continually refers to him as "it" while Hindley, son of Earnshaw, calls him "imp of Satan" (Wuthering Heights, pp. 29, 30, 32). When Hindley, upon the death of old Earnshaw, takes his place and dismisses Heathcliff from the domestic space and culture by terminating his education and making him work outdoors like other servants, the outsider position of Heathcliff is reinforced. His desire for vengeance leads to cruelty toward other characters. The Gothic conventions employed particularly in the portrayal of Heathcliff can be closely linked to class antagonisms in Victorian England. For Eagleton, the primary contradiction in the novel is "the choice posed for Catherine between Heathcliff and Edgar", with Heathcliff symbolising the 
"capitalist drive" (1975, pp. 101, 116). Heathcliff becomes one of bourgeoisie when he owns Wuthering Heights. After some time, he owns Thrushcross Grange which belongs to the gentry. Therefore, as it can be deduced from Eagleton's criticism of the novel, like his origins, Heathcliff's social position is ambiguous. The first impression he leaves on Mr. Lockwood, who is one of the narrators and a tenant at the Grange, is a contradictory one, which reveals this ambiguity:

Mr. Heathcliff forms a singular contrast to his abode and style of living. He is a darkskinned gypsy in aspect, in dress and manners a gentleman, that is, as much a gentleman as many a country squire: rather slovenly, perhaps, yet not looking amiss with his negligence, because he has an erect and handsome figure- and rather morose (Wuthering Heights, p. 5).

Heathcliff is both the master and the dark-skinned gipsy, both the oppressor and the oppressed. As an embodiment of all these, he stands for the ambiguous and thus resistant other that the novel seeks to keep in control in Jamesonian sense.

Like Bertha, who is the dark double of Jane, Heathcliff is the other, darker self of elder Catherine for Gilbert and Gubar. Heathcliff is Catherine's "desirous self", her "desirous id"; and they form a "wholeness, fullness of being" together (Gilbert \& Gubar, 1979, pp. 264, 282, 280, emphasis original). Since Heathcliff is presented to the family as a gift by old Earnshaw, he is replaced with the whip asked for by Catherine and the fiddle asked for by Hindley as a present. Gilbert and Gubar interpret this replacement and the function of Heathcliff in Catherine's life as follows:

'it' (both whip and brat) functions just as she must unconsciously have hoped it would, smashing her rival brother's fiddle and making a desirable third among the children in the family so as to insulate her from the pressure of her brother's domination (1979, p. 264).

Furthermore, it is Heathcliff's presence, as id, that makes Catherine question her gender roles established by the society which is associated with the superego. She is in one sense enculturated during the period she stays at Thrushcross Grange. Afterwards, she marries Edgar Linton in accord with the social norms and class consciousness though she is in love with Heathcliff. However, she suffers due to this choice. She cannot leave Edgar and be with her other self, Heathcliff. Heathcliff takes vengeance on her by flirting with Isabella, Catherine's sister-inlaw. Impossibility of their union and jealousy drive Catherine mad. She calls Isabella "my rival" because if Isabella marries Heathcliff, she will be his sexual partner, which is only a fantasy for Catherine (Wuthering Heights, p. 83). She experiences "psychic fragmentation" (Gilbert \& Gubar, 1979, p. 278). She shuts herself in a room and dismisses the duties of a wife. The novel criticises the institution of marriage which entraps women in certain conventions and expectations at this point. She yearns to see her lover once more, which is sort of adultery and transgression of the social mores. It is important to note that she is pregnant while experiencing this mental breakdown. So, her fear about giving birth could be one of the reasons that cause her mental breakdown. However, the novel does not dwell on this possibility. If Heathcliff functions as id in Catherine's life as Gilbert and Gubar argue, one can assume that the position of woman, her sexuality, desires, fears, and social institutions like marriage are problematised from over Heathcliff and the nature of her attraction to him.

It is not only the woman question dealt with from over the racial other, but also some other phobias and anxieties of English society that is driven with a strong sense of racial superiority in that period. Brantlinger touches on the racist theories dominant in the Victorian period and contends that these theories, which assumed white supremacy, were used to "explain Britain's industrial and imperial preeminence" and rationalise the imperialist cause (1988, p. 21). Portraying Heathcliff as an evil character who becomes a tyrant towards the end, the novel demonstrates that even at the peak of its imperial domination, Britain was haunted with panic 
and fear related to the colonies. Miscegenation was one cause of anxiety for the members of the Empire. It was assumed to lead to the contamination of the pure British blood. Marianna Torgovnick (as cited in Brantlinger, 2009) avers that miscegenation challenges the "boundary of the race" (p. 71). Possibly that is why Jane Eyre does not burden Rochester with a mixed-race offspring from Bertha. The same fear is evident in Wuthering Heights, too. It does not allow the union of the white English woman, Catherine, and the dark-skinned other, Heathcliff. The novel shows the ramifications of blood mixing through young Linton, Heathcliff and Isabella's son. As Maja-Lisa von Sneidern contends, "Emily Brontë creates Linton Heathcliff in the mold of the racialist stereotypes and anxieties of the time" (1995, p. 185). Linton is portrayed as a sickly, peevish, effeminate character who by no means arouses sympathy in the reader. He functions as the puppet of his father to carry out his evil plan which is to establish his own tyranny. Even Heathcliff disowns him. When he first sees the boy, he says, "Thou art thy mother's child, entirely! Where is my share in thee, puling chicken?" (Wuthering Heights, p. 160, emphasis original). Linton embodies the "worst accidents and mistakes mixed blood could represent for mid-century England: disease, viciousness, treason, cowardice, duplicity, unmerited power, shiftlessness" (Von Sneidern, 1995, p. 184). As a dangerous and repugnant effect of racial mixing, he does not fit into the Victorian concept of manliness. His death at an early age is a strategy for the novel to keep the domestic sphere clean and pure, which is an imaginary solution to the fear of miscegenation in the Victorian period.

As Heathcliff poses a threat to the social order with his homecomings, he can be the embodiment of a "reverse colonization" which is the "worst nightmare of the imperialist power" (Meyer, 1996, p. 112). He is surely of another race. By gaining old Earnshaw's sympathies, Heathcliff threatens Hindley's position at the Heights. There is a power struggle between them. Heathcliff manages to defeat him by leading him to bankruptcy. He is also in a power struggle with Edgar. He seduces Isabella, Edgar's sister, and marries her not out of love but out of desire for vengeance. Bertha is the abhorred woman with little intellect in the eyes of Rochester; yet, in this novel, it is Heathcliff, the non-British, who calls Isabella "pitiful, slavish, mean-minded brach . . . an abject thing" (Wuthering Heights, p. 118). He looks down on her as she sees him as "a hero of romance" (Wuthering Heights, p. 118). This sheds light on his superior position in marriage. Designing some plots, he owns the Grange ensuring his tyranny. "At the Heights, Heathcliff has usurped the dominant culture, and he has contaminated the Grange" (Von Sneidern, 1995, p. 180). Perhaps one of the reasons why he has to be exterminated at the closure of the text is to relieve Victorian readers from their anxiety about reverse colonization. Only after his death can the dominant cultural norms be reproduced.

Furthermore, Heathcliff is associated with cannibalism on some occasions, which is in keeping with the fear of being invaded because it implies transgression of boundaries and being the object of another one's desires (Meyer, 1996, p. 119). For example, Catherine, who sees Isabella being sexually drawn to Heathcliff, tells him that she will not let him "seize and devour her [Isabella] up" (Wuthering Heights, p. 84). Fear of cannibalism is reflected in the portrayal of Bertha, too. When Mason, her brother, visits her, she attacks him. He says that the woman bit her and "sucked the blood: she said she'd drain [his] heart" (Jane Eyre, p. 181). Similarly, when the madwoman visits her room and tries on Jane's veil, Jane is appalled by this vision as the visitor looks like a "foul German spectre-the Vampyre" (Jane Eyre, p. 242). Both novels associate the racial other with cannibalism and work out their own phobias of vampirism and cannibalism through the racial other. This can be an attempt to suppress the metaphorical vampirism inherent in the ideologies of colonialism and imperialism. When the repressed returns in the form of Bertha and Heathcliff, the only way to deal with it is to exterminate her/him. 
Heathcliff, as the embodiment of all of these fears and anxieties, is given his deserved end by the novel. His death is a source of celebration for most of the other characters. Joseph, one of the servants at the Heights, falls on his knees to thank God now that "the ancient stock were restored to their rights" (Wuthering Heights, p. 26). However, adding to the uncanny effect, though he is dead, he continues to haunt the Heights. According to Nelly, some country people say that they have seen him after his funeral walking on the moor, around the Heights, and even in its rooms (Wuthering Heights, p. 257). The compulsory repetition of the events, names, and returns of Heathcliff reflect the feeling of "helplessness" of the English in terms of the Freudian conception of the uncanny $(1899$, p. 144). Freud thinks that the "dominance of the compulsion to repeat" can be recognized "in the unconscious mind" (p. 145). Heathcliff represents "the return of the colonial repressed" who somehow manages to "get in" (Meyer, 1996, p.119). He occupies the centre of the Heights, then the Grange, hence the novel even when he is dead. Therefore, to use Jameson's terms, Wuthering Heights cannot manage to offer the desired "symbolic resolution of real political and social contradictions" (1983, p. 65).

Although there is no character to symbolise the colonized races in it, Great Expectations touches upon imperialism and colonial trade briefly. This novel is the one which is the most silent about what takes place at the periphery when compared to the others discussed above. The penal colony Australia is mentioned when the text deals with the transportation of the convicts. The issue of transportation can be regarded as the cleaning the homeland from the social pollution caused by criminals. Although the main concerns of the novel seem to be the issues of class hierarchy and mobility, and gentlemanliness in Victorian society, what takes place at the background informs us about the political unconscious of the text. If the polluting members of the society are sent to the colonial space, then homeland is configured as pure unlike the colonial space which is associated with impurity.

Great Expectations projects the real contradictions in the society onto the colonial space and tries to resolve them by making a here and there comparison. The Victorians were highly concerned with the problem of the surplus population. It was regarded as a burden on the economy of the country. It was also a threat to peace at home. In the late nineteenth century, Cecil Rhodes (as cited in Brantlinger, 1988), a statesman, reflected on the question of "how imperialism could serve as an alternative to socialism at home" as follows: "in order to save the ... inhabitants of the United Kingdom from a bloody civil war, we ... must acquire new lands to settle the surplus population, to provide new markets for the goods produced by them"' (p. 34). Who were regarded as members of this surplus or redundant population? Criminals and "all the poor-paupers, vagrants, landless Irish peasants, unemployed handloom weavers, idled factory workers. These were the 'dangerous classes' from whose ranks sprang criminals and incendiary types- Luddites, trade unionists, Chartists, socialists" (Brantlinger, 1988, p. 118). Magwitch belongs to this category. His criminal bent, as he expresses, is mostly due to the social problems such as poverty and unemployment that haunted the lives of thousands in Victorian England. $\mathrm{He}$ is victimized by Compeyson who has made use of him in some criminal acts for his own advantage. Like Jane, who likens herself to the inmates of the harem in order to challenge the masculine domination of Rochester, Magwitch states that Compeyson has made him his "black slave" (Great Expectations, p. 345). In fact, such an analogy in the portrayal of the relationship between these two characters aims to show the ill nature of Compeyson and to criticise the legal system which sides with the powerful and the upper-class. Nevertheless, as the weaker party is associated with the racially differentiated and the oppressed, it is evident that the problem at home is once more reflected in the text by means of the colonized. If Magwitch is the black slave, then, his homecoming after his experience in the colony presents what Brantlinger calls "a sociological 'return of the repressed"” (1988, pp. 120-121). As with Bertha and Heathcliff, 
there is one way for the text to deal with this return; and it is death. By this means, Victorian readers are relieved of their anxiety about anarchy and revolution of the lower class.

Like Rochester and Jane, Pip and his friend Herbert, who guides him in London on his path towards gentlemanliness, depend on the money made in the colonial space. Ironically, Pip's gentlemanliness is an illusion as it is a convict that makes him what he is. When Magwitch flees to England in order to meet Pip, he is proud of himself. He looks at Pip "with an air of admiring proprietorship" (Great Expectations, p. 329). Like Heathcliff who is examined just to be scorned by the Lintons, Pip at this point is objectified under the colonial gaze in one sense. Although his state is different from that of the dark-skinned other, still, Pip feels degraded for being owned by a convict. He feels "abhorrence", "dread", and "repugnance" upon recognising the true source of his fortune (Great Expectations, p. 315). Nevertheless, he never questions how a convict raises that sum in the colony. Although Pip is the focus of the text, and Herbert's doings are kept at the margins, tracing how Herbert earns his life sheds light on the economic exploitation of the colonies and the profits made by the members of the Empire. When they meet for the first time, Herbert informs Pip about his plans for the future. He wants to trade to "the East Indies, for silks, shawls, spices, dyes, drugs" and to "the West Indies, for sugar, tobacco, and rum. Also to Ceylon, specially for elephants' tusks" (Great Expectations, p. 182). Trade with the colonized is a great opportunity for him to make a fortune. His journeys to Marseilles and Cairo remain as the details which the text overlooks. Fascinated by the "magnificence of these transactions", Pip leaves England for Cairo to join him (Great Expectations, p. 182). He spends eleven years there, which enables his social progress after his great expectations are shattered.

As it is with Bertha and Heathcliff, Magwitch's return from the colony is represented by employing some conventions of the Gothic. Magwitch appears on a stormy night, out of darkness. Pip states that before Magwitch's appearance, he "has had mysterious warnings of this man's approach", heard pursuers "in every rage of wind and rush of rain", and "passed faces in the street which I had thought like his"; he adds that Magwitch's "wicked spirit had somehow sent these messengers to [him]" (Great Expectations, p. 319). The uncanny voices, faces and his ongoing sense of being followed by some unknown people reveal his hatred of the convict who haunts his life starting from the graveyard episode. When the convict comes back to England, he disturbs the order in Pip's life. The colonial traces in the form of a madwoman such as Bertha, a gipsy brat such as Heathcliff, or a convict rejected by the rest of the society keep intruding the order at the centre. They pose a threat to the rationality, civilisation and morality at the centre.

Although Magwitch's experiences in the penal colony as a corrupt member of the empire are not expressed overtly or in detail, some colonial references are present in the novel. For instance, Magwitch compares his gentleman to a colonist he has seen there and states that if a colonist has a horse then Pip must have one, too (Great Expectations, p. 328). On another occasion, when Pip is fed up with his unbearable connection to the convict, he thinks of leaving everything behind and enlisting "for India as a private soldier", which means a direct participation in the imperialist oppression of the races with darker skin (Great Expectations, p. 334). Besides, India can be a space he can keep away from the wretchedness of his life caused by Magwitch. When Magwitch dies, some papers and notes are found in his pockets. "Among these, were the name of a banking-house in New South Wales where a sum of money was, and the designation of certain lands of considerable value" (Great Expectations, p. 443). Magwitch intends these to be inherited by Pip. However, as the focus is on the development of a father and son bond between Pip and Magwitch followed by Magwitch's death, these references are not highlighted. Pip is made a gentleman due to the money coming from the colonies, which 
reminds one of the incomes of Rochester and Jane. Both texts focus on the protagonists keeping the reader rather ignorant about how these sums are made. This is the illusory resolution they offer as to the uneasiness about the Empire's economic dependency on its colonies.

The resolution in Great Expectations is similar to that of Jane Eyre as in both, the protagonist ends up being part of the imperialist project in one sense. After Magwitch's death, Pip decides to return to his village, with an intention to marry Biddy, a virtuous and sensible woman. However, when he learns that Joe and Biddy will get married, he joins Herbert in his trade company in Cairo. He mentions his partnership with Herbert as: "we had a good name, and worked for our profits, and did very well" (Great Expectations, p. 474). Ironically, Herbert has joined that company some time before due to Pip's intervention which is enabled by the money sent by Magwitch from Australia. At the very end, when he meets Estella after spending eleven years abroad, he tells her that he still lives "abroad" and "do[es] well" there (Great Expectations, p. 477). The conventional ending, namely marriage, does not take place in the end though there is an implication of it. However, with regard to the typical ending of a bildungsroman, Pip reconciles with the society by becoming one of those who help to sustain the Empire. Put differently, Pip comes to terms with the society and finds a place for himself in the external world through his vocation. Both Pip's and the Empire's economies flourish due to colonial trade.

In conclusion, history lurks at the margins of these three novels which seem to deal with the matters at home and in England. Although they seem to engage with domestic and social problems such as woman's social position and sexuality, class mobility, and some social ills, the novels handle these problems from over the colonized or the colonial space. Like Freudian return of the repressed, the colony and the colonized keep appearing in these novels. And they are almost always portrayed by using the Gothic conventions. On the one hand, these references or allusions point to the anxieties, fears, and fantasies of the society, and the contradictions between the British and the other races. On the other hand, they help to construct a certain understanding of national identity as opposed to the otherness of the racially differentiated party. If Bertha is a beast, Jane is an independent woman. If Heathcliff is a demon, a savage, Edgar Linton is a civilized man. If the dreadful convicts are sent to Australia, they become fatherly when they are back in England. The double function of the in-passing references points to the political unconscious of these novels which can be traced in "the Utopian dimension of [these] ideological texts" (Jameson, 1983, p. 289). The utopian dimension is obvious in the "imaginary resolutions" by which these texts resolve the social contradictions in the aesthetic realm because they are unresolvable in real life in Victorian England (Jameson, 1983, p. 173).

\section{References}

Brantlinger, P. (1988). Rule of darkness: British literature and imperialism 1830-1914. Ithaca and London: Cornell University Press.

Brantlinger, P. (2009). Victorian literature and postcolonial studies. Edinburgh: Edinburgh University Press.

Brontë, C. (2001). Jane Eyre. (3 ${ }^{\text {rd }}$ ed). Dunn, R. J. (Ed.). New York, London: W. W. Norton \& Company. (Original work published 1847)

Brontë, E. (2003). Wuthering heights. (4 ${ }^{\text {th }}$ ed). Dunn, R. J. (Ed.). New York, London: W. W Norton \& Company. (Original work published 1847)

Dickens, C. (2002). Great expectations. London: Penguin Books. (Original work published 1861). 
Eagleton, T. (1988). Myths of power: a Marxist study of the Brontës. (2 $2^{\text {nd }}$ ed.). Houndmills, Basingstoke, Hampshire: Macmillan Press. (Original work published 1975)

Freud, S. (2003). The uncanny. (D. McLintock, Trans.). New York: Penguin Books. (Original work published 1899)

Gilbert, S. M., \& Susan G. (2000). The madwoman in the attic: the woman writer and the nineteenth-century literary imagination. ( $\left.2^{\text {nd }} \mathrm{ed}\right)$. New Haven and London: Yale Nota Bene Yale University Press. (Original work published 1979)

Jameson, F. (1983). The political unconscious: narrative as a socially symbolic act. London, New York: Routledge.

Macherey, P. (2006). A theory of literary production. (G. Wall, Trans.). New York: Routledge. (Original work published 1966)

Meyer, S. (1966). Imperialism at home: race and Victorian women's fiction. Ithaca and London: Cornell University Press.

Michie, E. (1992). From simianized Irish to oriental despots: Heathcliff, Rochester and racial difference. NOVEL: A Forum on Fiction, 25(2), 125-140. Retrieved 04 June 2017 from:https://www.jstor.org/stable/pdf/1346001.pdf?ab_segments=0\%2Fdefault2\%2Fcontrol\&refreqid=search\%3A01292312517c5ba08b35ed03ad490cc 7 .

Said, E. W. (1994). Culture and imperialism. New York: Vintage.

Spivak, G. C. (1985). Three women's texts and a critique of imperialism. Critical Inquiry, 12(1), 243-261. Retrieved 07 March 2017 from: https://www.jstor.org/stable/pdf/1343469.pdf?ab_segments=0\%2Fdefault-2\%2Fcontrol\&refreqid $=$ search\%3A3940572cd461673bc01141726b5883ee.

Von Sneidern, M. (1995). Wuthering Heights and the Liverpool slave trade. ELH, 62(1), 171196. Retrieved 03 June 2017 from: https://www.jstor.org/stable/pdf/30030265.pdf?ab_segments $=0 \% 2$ Fdefault-2\%2Fcontrol\&refreqid=search\%3 Af8e8e001dbd29c08db06cbc073444047. 